\title{
RESEARCH PAPER \\ HYDROGEOLOGICAL EVALUATION OF GEOLOGICAL FORMATIONS IN ASHANTI REGION, GHANA
}

\author{
I. Osei-Nuamah and "E. K. Appiah-Adjei \\ Geological Engineering Department, College of Engineering, KNUST, Kumasi \\ *Corresponding author: emmaappiah_adjei@yahoo.comorekappiah-adjei.soe@knust.edu.gh
}

\begin{abstract}
The success of groundwater exploitation in an area largely depends on prior knowledge of existing hydrogeological parameters such as borehole yield, overburden thickness, depth of boreholes, static water level, specific capacity and the quality of water. This study, therefore, employed Geographical Information System to assess some of these hydrogeological parameters in the Ashanti Region using the ordinary kriging interpolation method. Data on 2,788 drilled boreholes in the region were used and the assessment focused on the various geological formations in the region that comprised the Birimian, Granitoids, Tarkwaian and Voltaian formations. The study results indicate that the Birimian formation is generally within medium to high yielding potential zones (30 - $60 \mathrm{l} / \mathrm{min}$ or higher) with a high drilling success rate of $91 \%$ and average borehole depth of $53 \mathrm{~m}$. The Granitoids are, mostly, within the low yielding zone (<30 l/min) with isolated high yielding boreholes and have average borehole depth and drilling success rate of $50 \mathrm{~m}$ and $72 \%$ respectively. The Tarkwaian formation, on other hand, is within the medium yield zone with a drilling success rate of $80 \%$ whilst the Voltaian formation is mainly classified to fall within low yield zone with about $60 \%$ success rate although significant high yield zones occur within the sandstone formation underlying its westernmost part in the region. Groundwater in the region is generally potable except in a few locations within the Birimian and Granitoids, where there are problems with levels of iron, nitrate, manganese and $\mathrm{pH}$.
\end{abstract}

Keywords: Groundwater, Hydrogeological parameters, Geological formations, Geographical Information System, Ashanti Region

\section{INTRODUCTION}

Groundwater is an essential resource for sustainable development all over the world. In Ghana, it is becoming the most important source of water for domestic, industrial and agricultural purposes due to the unreliability of surface water sources, which often become vulnerable in the dry season and are easily polluted by industrial waste, artisanal mining activities and leaching of pesticides, fungicides 
and fertilisers used for agricultural purposes (Nyarko et al., 2014). It is, mainly, abstracted using boreholes and hand dug wells (HDW) and has contributed tremendously in reducing several water-borne diseases in the country.

Groundwater usage has become attractive in Ghana because the aquifers are protected naturally from evaporation. They are more reliable in dry seasons because of their large storage capacities and they exist in most parts of the country where they are exploited at shallow depths and near demand areas without the need to install long distribution lines. Consequently, in the Ashanti Region and other parts of Ghana, the Government of Ghana and several nongovernmental organisations (NGO) have been providing rural communities with boreholes and hand-dug wells (HDW) to meet their drinking and other domestic water needs.

Despite its usefulness, accessing groundwater in Ghana comes with some challenges especially in the planning stage due to lack of information on parameters such as overburden thickness, expected drilling depth, quantity of water, the water quality and hydraulic properties of the geological formations, which are very key for decision-making regarding site selections and proper budgeting. In the Ashanti Region, for instance, some areas that are underlain by granitic and Voltaian rocks are known to have poor yields (Anornu et al., 2009) whereas some other areas are known to have poor water quality arising from high levels of iron, manganese, fluoride, arsenic and turbidity (Nyarko et al., 2014; Gyau-Boakye and Dapaah-Siakwan, 2000; Anornu et al., 2009). These information help in proper planning and budgeting for drilling projects in such areas to ensure they are successful.

It is therefore evident that if some of these hydrogeological information for prospective projects are available, the budget, duration, likely challenges and the appropriate remedies can be adequately planned to enhance the smooth implementation of the project. With advances in
Geographical Information System (GIS), software with user-friendly pre-processing and post -processing interfaces that use digital techniques to integrate various conventional methods (geological and hydrogeological) with remote sensing (RS) techniques are available for storing and visualising the data as well as for the prediction of future conditions (Kresic and Mikszweski, 2013; Chenini et al., 2010; Machiwal et al., 2011; Talabi and Tijani, 2011).

Therefore, this study seeks to employ GIS techniques to evaluate and delineate the hydrogeological parameters of the various geological formations in the Ashanti Region to aid in easy and successful exploitation of groundwater. The ArcGIS software was used to assess secondary data of existing boreholes and produce surface maps of some of the hydrogeological parameters of the formations in the study area including the airlift yield, overburden depth, final depth of successful boreholes, static water level elevation, and specific capacity employing the ordinary kriging interpolation method. The study also analysed the quality of water in the various geological formations.

\section{MATERIALS AND METHODS}

\section{Study area}

The Ashanti Region is located in the middle belt of Ghana between longitudes $0.15^{\circ} \mathrm{W}$ to $2.25^{\circ} \mathrm{W}$ and latitudes $5.50^{\circ} \mathrm{N}$ to $7.46^{\circ} \mathrm{N}$. The region covers about $10.2 \%\left(24,389 \mathrm{~km}^{2}\right)$ of Ghana's total land area, making it the third largest region after the Northern and BrongAhafo Regions (MLGRD, 2016). Nearly $61 \%$ of the region's population $(4,780,380)$ lives in urban areas with more than $92 \%$ of them having access to 'improved' (piped-system, boreholes and protected HDW) source of drinking water with groundwater via boreholes and protected wells constituting $42 \%$. About $6.5 \%$ of the inhabitants still rely on unprotected sources (HDW, dug outs, streams and rivers) for drinking water (GSS, 2013).

Two main lithostratigraphic/lithotectonic complexes, namely: the Paleoproterozoic su- 
pracrustal and intrusive rocks, and the Neoproterozoic to early Cambrian lithologically diverse platform sediments, exist in the study area (GSD and BGR, 2009). The Paleoproterozoic rocks consist of the Birimian Super group (Birimian sediments and volcanics, which consist of metamorphosed sediments intercalated with metamorphosed tuff and intruded lava), Tarkwaian Group (made up of quartzites, phyllites, grits and conglomerates intruded by laccoliths and sills of epidorite), and the Eburnean Plutonic Suite (comprising undifferentiated granitoids such as granites, granodiorites and gneiss). On the other hand, the Neoproterozoic to early Cambrian rocks comprise the VoltaianSuper group made up of the Kwahu-Morago, Oti-Pendjari and Obosum Groups, which are underlain by basal sandstones consisting mainly of quartz-sandstone, pebbly grits, shale, mudstone, siltstone, sandstone, arkose and con- glomerate (Gill, 1969; Kesse, 1985; DapaahSiakwan and Gyau-Boakye, 2000). Fig. 1 presents the geological formations in the study area.

\section{Data acquisition and organisation}

Borehole drilling records in the study area (Fig. 1) spanning from 1991 to 2011 were collated from hydrogeological reports submitted by Consultants for different borehole drilling projects under the supervision of the Ashanti Regional branch of the Community Water and Sanitation Agency (CWSA). The information culled from the reports included GPS coordinates of the boreholes in UTM Zone $30 \mathrm{~N}$ format and their elevation with respect to mean sea level (msl), borehole construction details such as final constructed depth, location of slotted and plain PVC pipes and gravel pack positions, geological logs detailing different

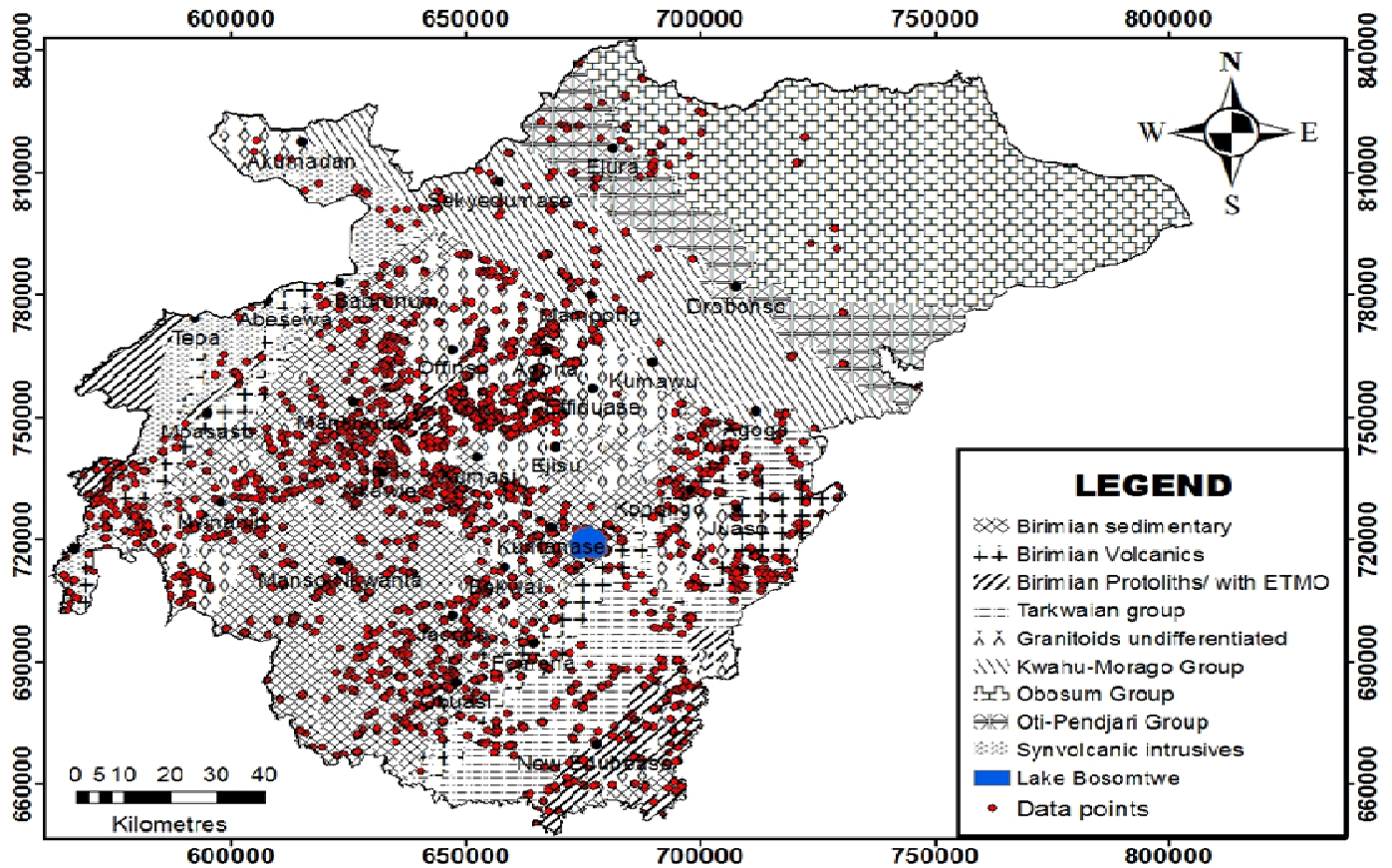

Fig. 1: Map of study area with the data locations on the geological formations 
different rocks intercepted at different depths, overburden thickness and depths at which water was struck. The others are the volume of water obtained at specific depths expressed in litres per minute $(1 / \mathrm{min})$, the final airlift yield recorded during development, and summary of pumping test results including the pumping yield, static water level (SWL), dynamic water level (DWL) after six (6) hours of pumping and three (3) hours recovery data as well as results of physico-chemical and bacteriological analyses of the water samples. The geological, district, hydrogeological and town maps of the study area were obtained from the Centre for Remote Sensing and Geographical Information Services (CERSGIS) of the University of Ghana and the GIS Laboratory of KNUST.

The data were organised into the various hydrogeological sub-provinces within the study area; namely the Birimian and its associated metasediments (Birimian), undifferentiated granitoids (Granitoids), Tarkwaian, and the Voltaian as Kwahu-Morago, Oti-Pendjari and Obosum Groups. The boreholes with airlift yield more than $13.5 \mathrm{l} / \mathrm{min}$ were termed successful whilst those below were deemed unsuccessful in accordance with the criteria set by CWSA (CWSA, 2010). The data was randomly divided into two parts termed training $(90 \%)$ and test data $(10 \%)$ using ArcGIS version 10.2.1 software. The training data was used for analyses and generation of maps whilst the test data was used to validate the results.

\section{DATA INTERPRETATION AND ANALY- SIS}

The geostatistical analyst tool in the ArcGIS version 10.2.1 software was used to analyse the spatial distribution of the data and produce maps to aid in the visual appreciation of the hydrogeology of the study area using the ordinary kriging interpolation method. For comparison purposes, similar surfaces were generated using the Inverse Distance Weighting (IDW) and Local Polynomial (LP) methods.

The distribution of each dataset was examined to ascertain whether it is normally distributed using the histogram and the normal QuantileQuantile (QQ) plot tools. Trends observed in some of the distributions were removed using the appropriate equation upon analyses with the trend analytical tool. Parameters such as lag size, nugget, range, partial sill and shape were set to fit the model using the spatial relationships of the dataset. Each dataset was examined to ascertain the existence of anisotropic (directional) influence. The maximum and minimum number of data, the radius and number of sectors of the circle or ellipse used for the prediction were also specified from the "searching neighbourhood" dialog box. A cross -validation comparison was done to select the model with the most accurate predictions using their resultant prediction error statistics (PES). The model that produced the best crossvalidation and test data validation prediction errors was selected. The test data was further plotted on maps generated using all the interpolation methods, i.e. kriging, inverse distance weighting (IDW) and local polynomial (LP), to determine the one with the best results. Surface maps were created for the depth of successful boreholes, overburden thickness, airlift yield, SWL, and specific capacity.

The available water quality results of the boreholes were collated and analysed to ascertain their suitability for drinking by comparing their quality to the Ghana Standards. The analyses were done for each geological formation and compared with each other. A surface map similar to what was produced for the hydrogeological parameters was produced for iron, which is the major water quality problem observed from the analytical results.

\section{RESULTS AND DISCUSSION}

Records of 2,788 boreholes comprising 2,331 constructed boreholes, 433 dry and 24 abandoned holes (due to their poor water quality) were finally accepted and used for the study (Fig. 1) and are summarised in Table 1. The number of successful boreholes within the Birimian, Granitoids, Tarkwaian, Kwahu- 
Morago, Oti-Pendjari and the Obosum were 1159, 757, 230, 54, 18 and 26 respectively.

The number of samples, data transformations and trend removals used in generating each of the maps are presented in Table 2. The model type and PES (i.e. mean error (ME), mean standardised error (MSE), root mean square error (RMSE), RMSE standardised (RMSEs) and averaged standard error (ASE)) for each parameter are also presented in Table 2.

The prediction results for the hydrogeological parameters using the test data are presented in Table 3 whilst the percentage of test data that fell within exact zones of the map generated using the three interpolation methods are presented in Table 4. The SWL elevation map had the best predictions for all the methods followed by the iron concentration map. Although the IDW had the best results for the iron concentration map, it failed to correctly predict any of the test data with respect to the higher values of iron above the Ghana Standard; thus kriging, which had $60 \%$ prediction accuracy, was used for the analyses.

\section{Evaluation of hydrogeological parameters Airlift yield}

The Birimian, Granitoids and Tarkwaian formations had average airlift yields of $89 \mathrm{l} / \mathrm{min}$, $52 \mathrm{l} / \mathrm{min}$ and $41 \mathrm{l} / \mathrm{min}$ respectively. The successful boreholes within the Kwahu-Morago, Oti-Pendjari and the Obosum Groups had mean airlift yields of 66,77 and $68 \mathrm{l} / \mathrm{min}$ respectively.

Fig. 2 presents an overlay of the airlift yield map generated on the geological formations. Three distinct zones are seen from the map; i.e. yields below $30 \mathrm{l} / \mathrm{min}$ (shades of green), yields between 30 and $60 \mathrm{l} / \mathrm{min}$ (yellow) and yields above $60 \mathrm{l} / \mathrm{min}$ (shades of red). These are termed low, medium and high yield zones for the purposes of this study. The Birimian sediments are generally noted to be within the medium and high yield zones as indicated by a NW-SE trend from the east of Abesewa to the South of Obuasi and a NE - SW trend, which

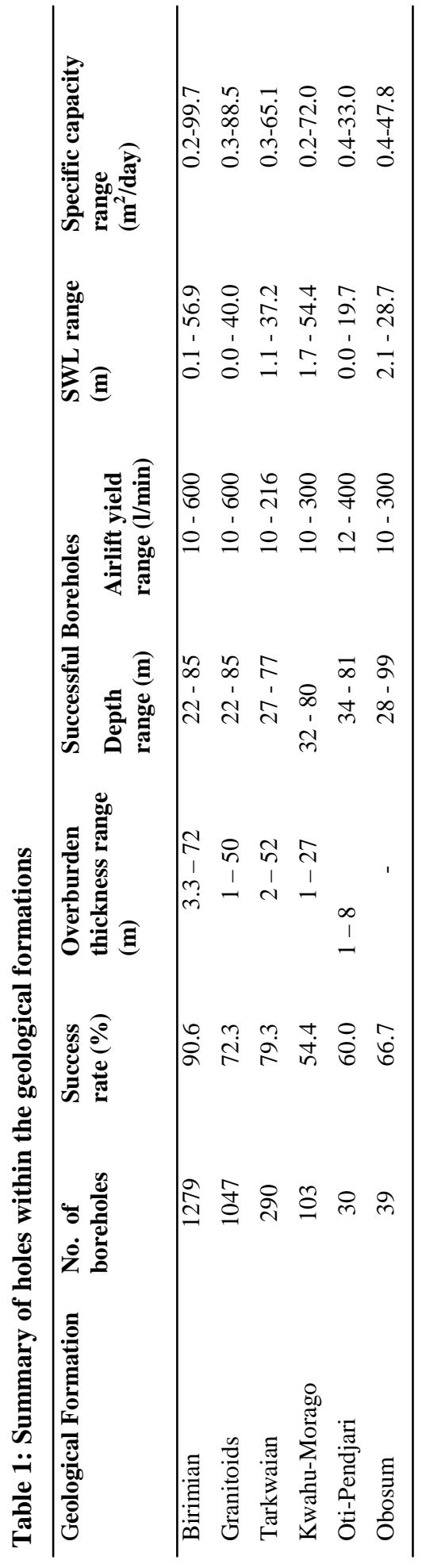

Journal of Science and Technology @ KNUST April 2017 
39

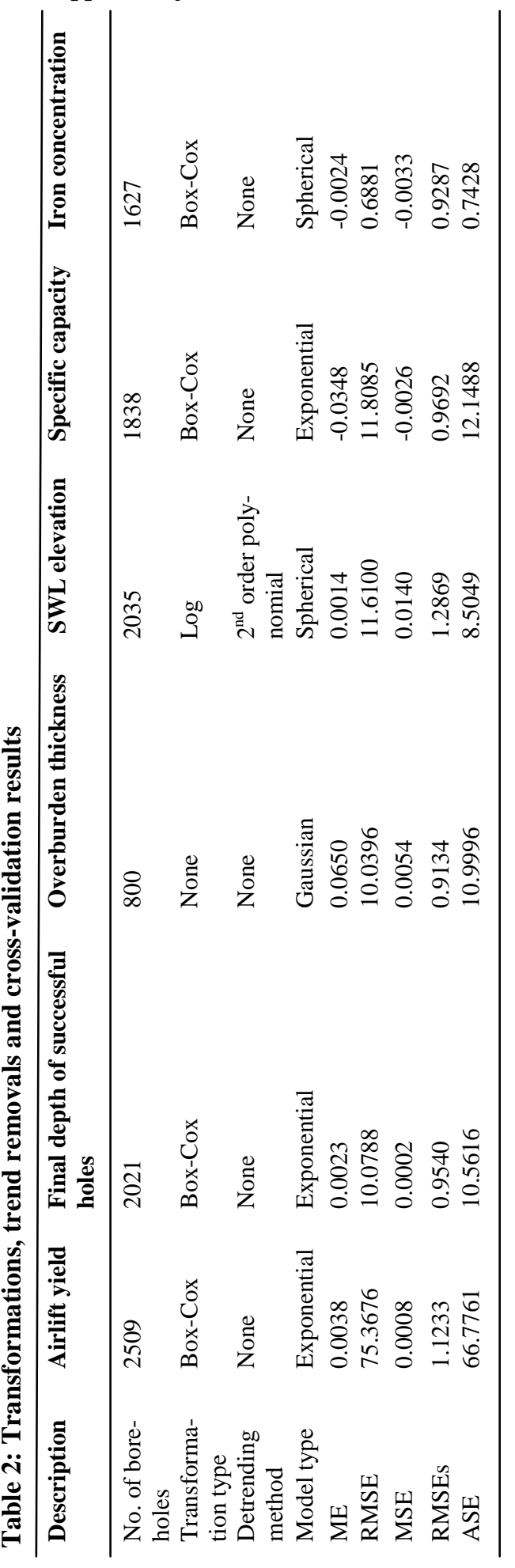

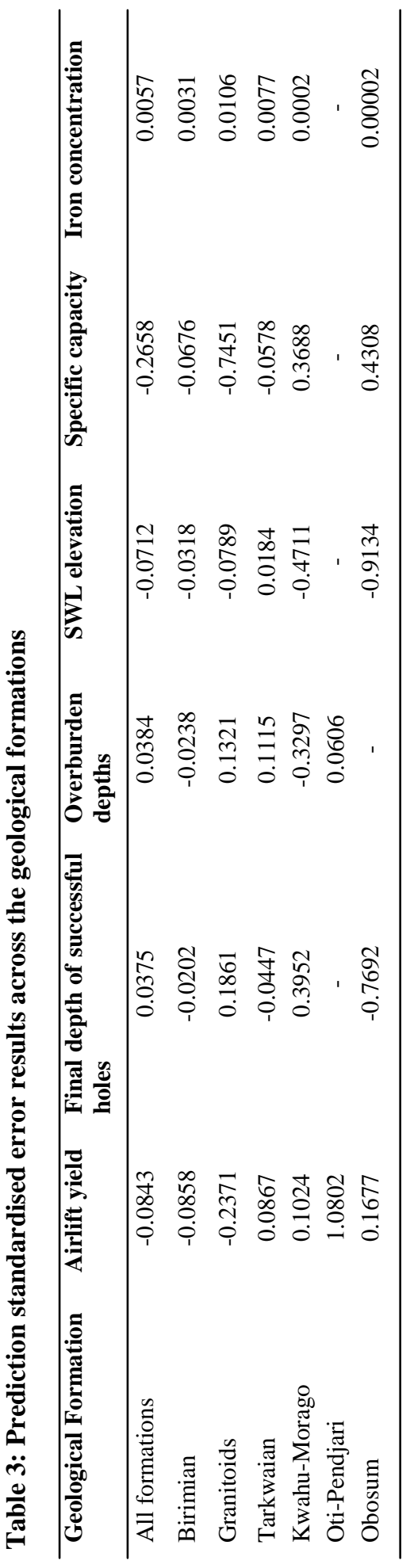


Evaluating the hydrogeology of Ashanti Region... 40

Table 4: Accuracy of test data in target zones on parameter maps

\begin{tabular}{lccc}
\hline Hydrogeological parameter & Kriging & $\begin{array}{c}\text { Interpolation method } \\
\text { Inverse Distance Weighting }\end{array}$ & Local Polynomial \\
\hline Airlift yield & 55 & 52 & 46 \\
Success depth & 37 & 39 & 32 \\
Overburden depth & 47 & 56 & 49 \\
SWL elevation & 91 & 90 & 91 \\
Specific capacity & 49 & 43 & 47 \\
Iron content & 78 & 83 & 63 \\
\hline
\end{tabular}

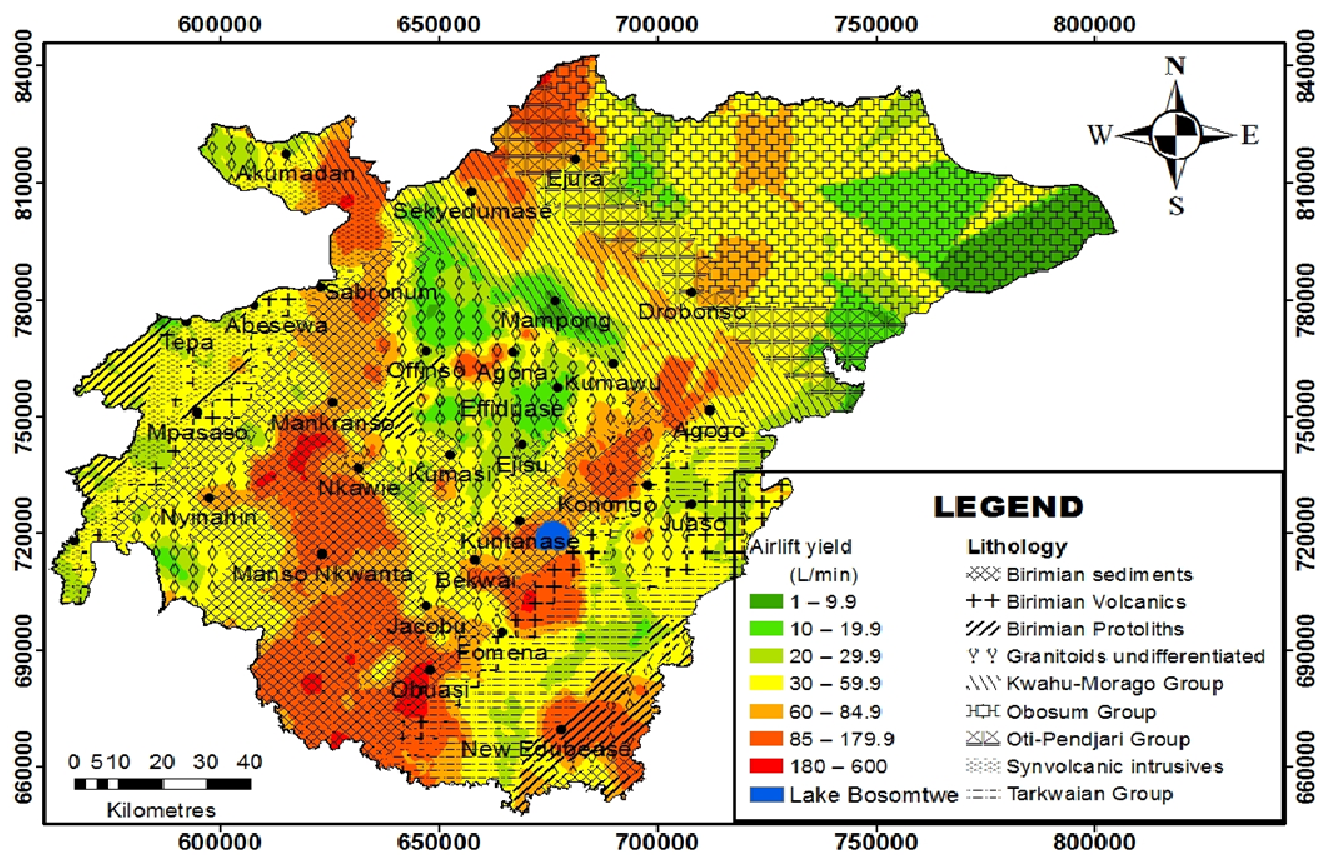

Fig. 2: Overlay of airlift yield on the geological formations

begins NW of Agogo through areas around the Lake Bosomtwe and ends just south of Fomena. Another high yield zone is located in the Birimian formation, east of New of New Edubiase, and may be attributed to the presence of structural features such as well-developed joints, fractures and strongly foliated systems as well as the presence of quartz veins within the formation, which has increased its waterbearing and yielding capacity (Gill, 1969; Dapaah-Siakwan and Gyau-Boakye, 2000). 


\section{Appiah-Adjei and Osei-Nuamah}

The Granitoids are generally within the lowyield zone as observed just beneath the central portions of the Kwahu Group. A high-yield zone in the granitoids is located along the stretch between Offinso and Agona. Similarly, a high yield zone is found within the synvolcanic intrusive rocks south east of Akumadan. This means that although the Granitoids are inherently impermeable they do exhibit secondary porosity and permeability as a result of fracturing and weathering (Dapaah-Siakwan and Gyau-Boakye, 2000; Gill, 1969; Kesse, 1985). The availability and connectivity of joints and fractures control groundwater flow within the crystalline rocks (Singhal and Gupta, 1999; Cook, 2003). From the study, it is observed that the synvolcanic granitoids yield significant amount of groundwater than the undifferentiated intrusive granitoids, which may be due to the fact that the former has welldeveloped and connected fractures than the latter. It must, however, be stated that isolated high-yielding boreholes were also recorded within the Eburnean plutonic granitoids.

Within the Voltaian Super group, all the yield zones are present with an overlap of zones amongst the sub-groups. The western half of the Obosum Group (where data was obtained) are low, medium and high yield zones moving towards the western border. Groundwater occurrence in the Voltaian formation is controlled by secondary porosity (Asomaning, 1993), which is mostly exhibited by the sandstones due to the presence of joints and fractures. Areas underlain by sandstones therefore produce much water than those underlain by mudstones and siltstones due to the absence of secondary porosity in the latter (Acheampong and Hess, 1998). According to Yidana et al. (2008), there is a NNE-SSW fracture system that controls the hydrogeology of the Voltaian formation in general. A similar trend is observed in the study area beginning from the north westernmost part of the Obosum Group (north of Ejura) and extends through the Oti-Pendjari Group, and finally terminates within the Kwahu-Morago Group. The lower portion of the Kwahu-
Morago Group is generally not favourable for groundwater development. About 36 out of 51 boreholes yielded less than $10 \mathrm{l} / \mathrm{min}$ at a mean depth of $69 \mathrm{~m}$.

The prediction standardised results (Table 3) using the test data shows that the airlift yield predictions are very good (closer 0 ) for all formations except the Oti-Pendjari Group. When the test data was plotted on the airlift yield map (Fig. 2), about $55 \%$ of them fell within the expected zones. The major deviation was the location of low yielding boreholes within a higher yield zone. In some instances, especially within the Granitoids and Birimian sediments, data points were located within yield zones lower than their yields. For those that did not fall within their expected zones, about $72 \%$ of them fell within a higher zone.

Some factors that may account for the deviations are inability to install temporary casings in deeper overburden depth areas resulting in tapping water within the overburden instead of drilling through the bedrock, which usually has less yield, and the non-connectivity of joints and fractures. Within the granitoids, for example, it is possible to locate a high-yielding borehole within a low-yield zone as groundwater flow is controlled by the availability and connectivity of joints and fractures.

\section{Depth of successful boreholes}

The successful boreholes in the Birimian and Obosum Group had mean depths of $53 \mathrm{~m}$ whilst the Granitoids, Tarkwaian, Kwahu-Morago and Oti-Pendjari Groups had mean depths of $50 \mathrm{~m}$. Final depths of the unsuccessful boreholes were deeper than the successful ones averaging 69, 63, 69, 76, 88 and $86 \mathrm{~m}$ depth for the Birimian, Granitoids, Tarkwaian, Kwahu-Morago, OtiPendjari and Obosum Group respectively. The mean depths of successful boreholes within the Birimian and Granitoids from this study are almost the same as the 51 and $53 \mathrm{~m}$ obtained by Anornu et al. (2009) in their studies in the Ejisu -Juaben District and comparable with $35 \mathrm{~m}$ and $60 \mathrm{~m}$ respectively obtained by Dapaah-Siakwan 
and Gyau-Boakye (2000) for their studies, which covered the whole of Ghana.

The map showing the depth of successful boreholes is presented in Fig. 3. A larger portion of the study area lies within the $40-50 \mathrm{~m}$ and 50 - $60 \mathrm{~m}$ zones and is characteristic of all the geological formations with an overlap of zones at various geological contacts. Similarly isolated areas with borehole depths of more than $60 \mathrm{~m}$ also exist within all the formations. The standardised predicted results (Table 3) using the test data shows that predictions for the depth of successful boreholes were very good for the Birimian and Tarkwaian Group, but poor within the Voltaian Super group, especially within the Obosum Group, which can largely be attributed to limited data relative to its large area. When the test data was plotted on the borehole depth map, only $37 \%$ of them fell within the exact zones but increased to $68 \%$ with a plus or minus of 5 metres. Within the
Voltaian Super group, very few of them fell within their expected zones, which may be attributed to the sparse distribution of the data. The major deviation within the other formations was the location of boreholes with depths greater than $60 \mathrm{~m}$ falling within lower depth zones.

\section{Overburden depth}

The data points available for overburden depths were 895. They comprised388within the Birimian, 344 for Granitoids, 133 for Tarkwaian, 23 for Kwahu Morago and7 for OtiPendjari; and their respective means were 27, 24, 20, 7 and 5. There was no data available for the Obosum Group.

Three major overburden thickness zones, namely $0-10,10-20$ and $20-30 \mathrm{~m}$ were delineated from the overburden map (Fig. 4). A fourth zone of more than $40 \mathrm{~m}$ is also recognised within the Birimian rock formations. The

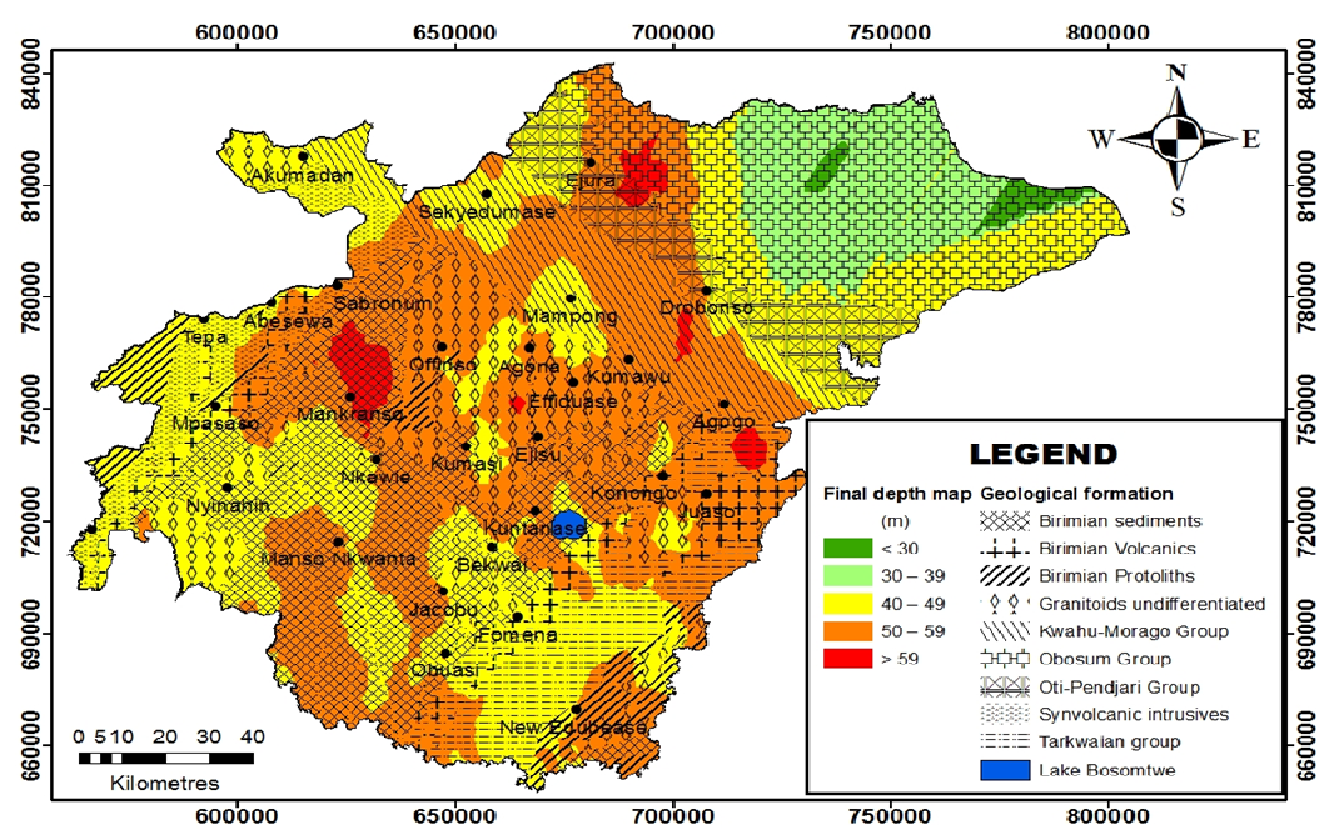

Fig. 3: Overlay of borehole depth on geology 


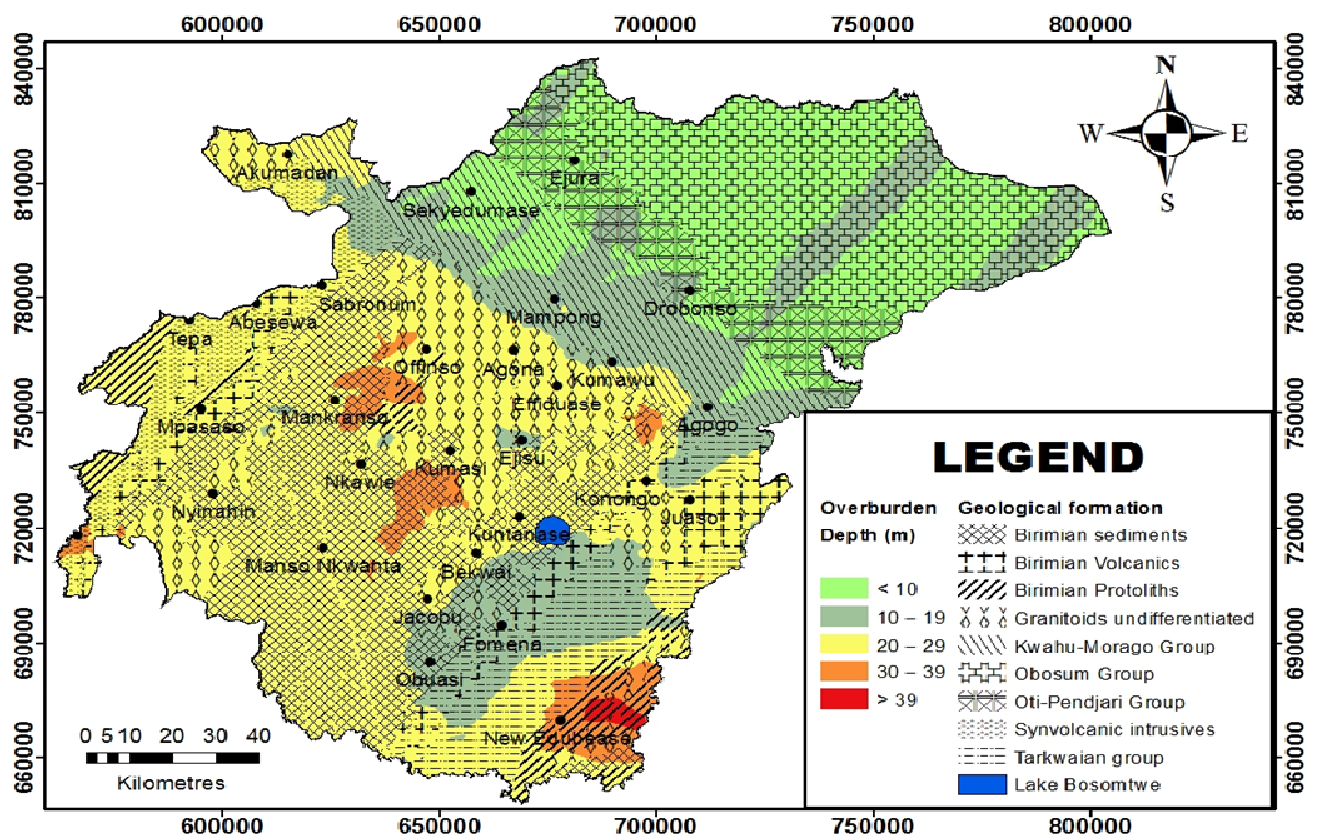

Fig. 4: Overlay of overburden thickness on the various geological formations

overburden thickness is of significant importance to a prospective groundwater developer as it impacts on the length of temporary casings to install to prevent caving during drilling. Also, the occurrence of significant amount of water in the overburden and at the overburdenbedrock contact mostly contributes significantly to success of boreholes. Thick overburden in Birimian and Tarkwaian Groups as well as areas underlain by the Granitoids typically cave in during drilling, thereby posing difficulty in constructing the borehole or it may lead to increased turbidity of the water when gravel-packing (filter media) do not descend to cover the entire slotted PVC section. About 13 of such cases were recorded in this study with all the boreholes eventually being abandoned. The Voltaian Super group generally has shallow weathering depths posing no significant problems during drilling.
Studies have shown that the contact between the saprolite and the saprock is the most productive groundwater zone within the BirimianSuper group as they usually complement each other in terms of permeability and storage (Carrier et al., 2008). Out of the 757 constructed boreholes whose overburden thicknesses were obtained, about $38 \%$ had their slotted PVCs placed within the overburden or about $5 \mathrm{~m}$ below the overburden and bedrock contact. Within the crystalline granitoids, more than $34 \%$ of them tapped water within the saprolite with more than $72 \%$ having overburden thickness greater than $20 \mathrm{~m}$, which confirms the results obtained by Asomaning (1993) that deep regolith layers overlie the crystalline basement rocks and provide potential for increased groundwater storage. The number of dry boreholes was observed to increase with increasing overburden depths and the mean airlift yields of the successful boreholes did not increase with 
Evaluating the hydrogeology of Ashanti Region... 44

increasing overburden thickness in the intense weathering formations (Table 5). This observation means that the assertion by DapaahSiakwan and Gyau-Boakye (2000) and Yidana et al. (2008) that intense weathering enhances secondary permeability to form permeable groundwater reservoirs have noticeable exceptions.

The predicted standardised results (Table 4) for the overburden thickness were very good for all the geological formations. When the test data was plotted on the overburden thickness, only $47 \%$ of them fell within the expected zones. The major deviation was the locations of boreholes with overburden thicknesses higher than $30 \mathrm{~m}$ in the $20-30 \mathrm{~m}$ zone. This is predominant in areas underlain by the Granitoids and the Birimian sediments.

\section{Static water elevation (SWL)}

The SWL values of 2,017 boreholes were available and they ranged from just below the ground level $(0.04 \mathrm{~m})$ to $56.92 \mathrm{~m}$. An artesian flowing borehole with SWL of $2.86 \mathrm{~m}$ above ground level was recorded within the granitoids. The average SWL values of $14 \mathrm{~m}, 13 \mathrm{~m}$, $12 \mathrm{~m}, 19 \mathrm{~m}, 8 \mathrm{~m}$ and $11 \mathrm{~m}$ for the Birimian, Granitoids, Tarkwaian, Kwahu-Morago, OtiPendjari and Obosum Group, respectively, indicate that the SWL is generally not deep in the region.

The SWL elevation map (Fig. 5) generally mimics the general topography of the study area with the highest point around Nsuta and north of Wiamoase within the Kwahu-Morago Group, but progressively decreases outwards to the adjoining formations. Two other higher elevations are located south of Mpasaso (within Birimian sediments) and Agogo (within Kwahu -Morago Group). There is a general decrease in SWL elevation towards both the south and north of the Kwahu-Morago Group.

The accuracy of predictions was very good for the SWL elevation map from both validation results. From the location of the test data within the generated zones (Table 4), about $91 \%$ of them fell within their expected zones with the kriging method. The Kwahu-Morago and OtiPendjari Groups within the Voltaian Supergroup had the least accuracy of prediction as seen from the predicted standardised error results (Table 3 ).

\section{Specific capacity}

The specific capacity values of the formations within the study area for 1,838 of the data had mean and standard deviations of $8 \mathrm{~m}^{2} / \mathrm{d}$ and 12 $\mathrm{m}^{2} /$ day respectively. The Oti-Pendjari Group had the narrowest range of specific capacities with the Birimian recording the widest range.

The specific capacity map is presented in Fig. 6. A greater part of the aquifers in the study area have specific capacities below $10 \mathrm{~m}^{2} /$ day followed by zones between 10 and $15 \mathrm{~m}^{2} /$ day.

Table 5: Mean airlift yield and dry boreholes in the overburden categories

\begin{tabular}{ccccccc}
\hline $\begin{array}{l}\text { Overburden } \\
\text { depth range }\end{array}$ & $\begin{array}{l}\text { Birimian } \\
\text { Mean airlift } \\
\text { yield (1/min) }\end{array}$ & $\begin{array}{l}\text { No. of dry } \\
\text { boreholes }\end{array}$ & $\begin{array}{l}\text { Granitoids } \\
\text { Mean airlift } \\
\text { yield (1/min) }\end{array}$ & $\begin{array}{l}\text { No. of dry } \\
\text { boreholes }\end{array}$ & $\begin{array}{l}\text { Tarkwaian Group } \\
\text { Mean airlift } \\
\text { yield (1/min) }\end{array}$ & $\begin{array}{l}\text { No. of dry } \\
\text { boreholes }\end{array}$ \\
\hline $0-10$ & 85 & 3 & 67 & 17 & 55 & 6 \\
$10-20$ & 111 & 9 & 59 & 19 & 43 & 10 \\
$20-30$ & 109 & 15 & 66 & 39 & 36 & 6 \\
Above 30 & 64 & 15 & 52 & 26 & 42 & 5 \\
\hline
\end{tabular}




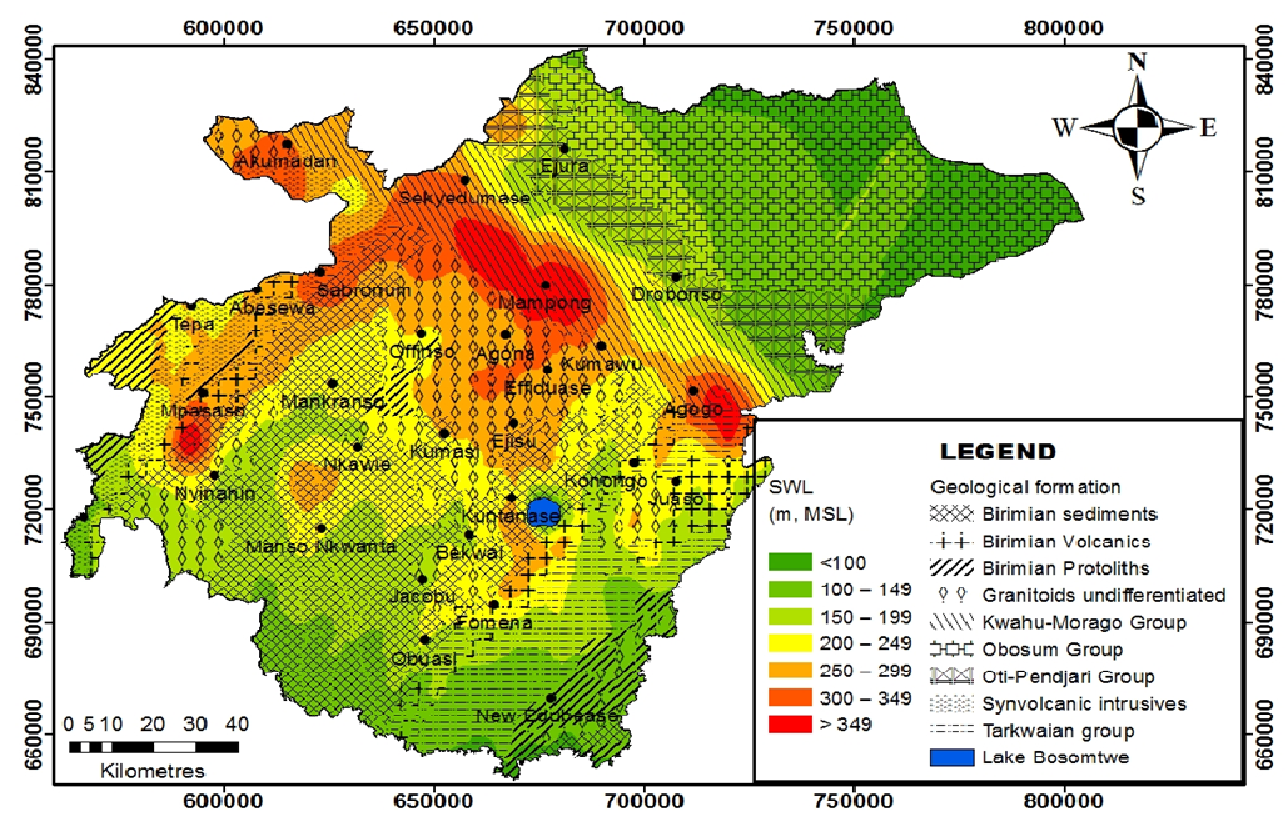

Fig. 5: Overlay of SWL elevation on the geology

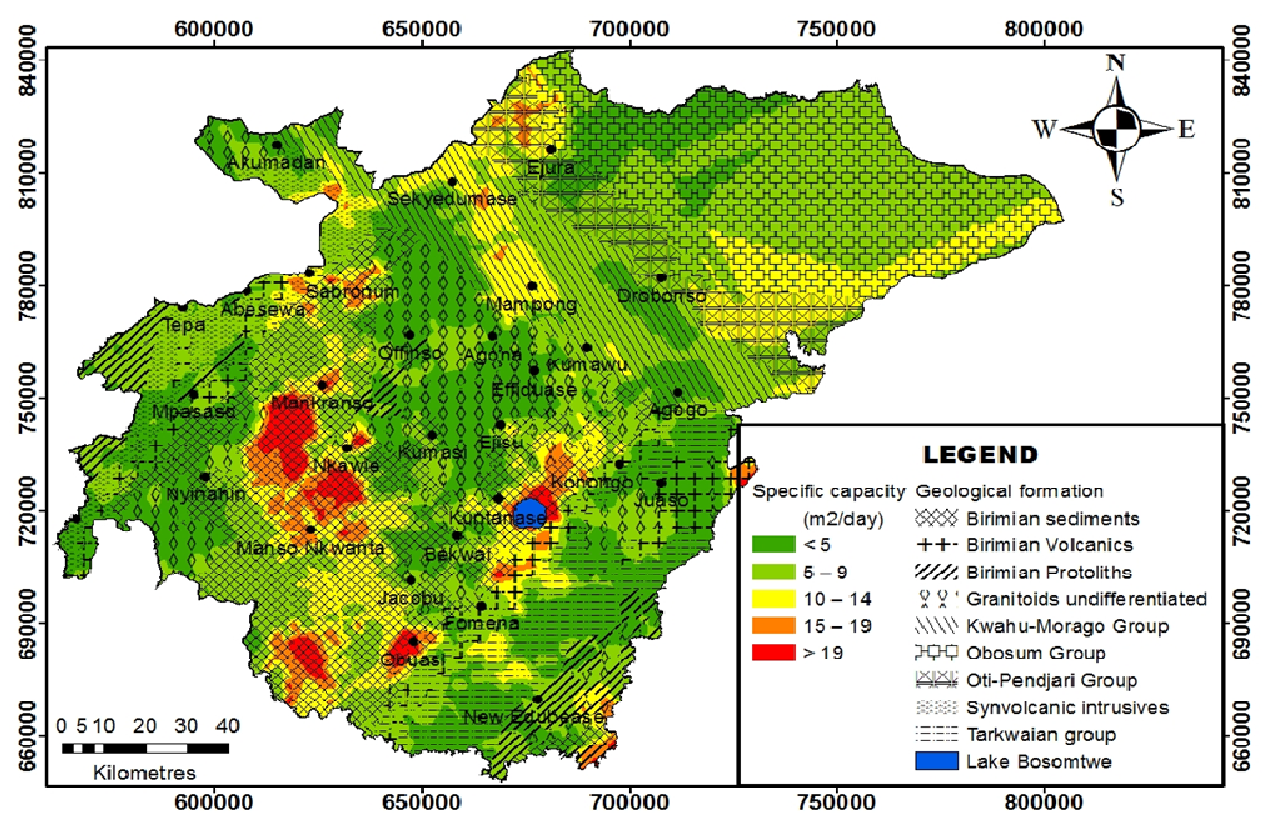

Fig. 6: Variation of specific capacity in the formations of Ashanti Region 
Evaluating the hydrogeology of Ashanti Region... 46

Only the Birimian and Tarkwaian Group had prediction standard errors that were closer to zero (0) as presented in Table 3. The accuracy of predictions within the Granitoids was the poorest among the formations analysed, which may be attributed to their crystalline nature.

\section{Water quality analyses}

Records pertaining to the quality of 1,627 boreholes were collated with about $21 \%$ having values outside the Ghana Standard (GS) for physico-chemical parameters. The major parameters that contributed to the poor water quality (PWQ) were $\mathrm{pH}(36.8 \%)$, iron (51.6\%), manganese $(6.5 \%)$, nitrate $(2.2 \%)$ and minor occurrences of others such as arsenic, fluoride and lead (Table 6). About $8.6 \%$ of the poor water quality boreholes had multiple problems in relation to $\mathrm{pH}$, iron, manganese, nitrate and arsenic. Their occurrences are prevalent within the Birimian, the Granitoids, Tarkwaian Group and the Kwahu-Morago Group (Fig. 7). Higher values of fluoride were recorded within the Kwahu-Morago (range of $1.8-2.4 \mathrm{mg} / \mathrm{l}$ ) and Oti-Pendjari (3.0 mg/l) Groups. The only occurrence of lead $(\mathrm{Pb})$ above the GS was recorded within the Kwahu-Morago Group with a value of $4.5 \mathrm{mg} / \mathrm{l}$. Similarly, higher values of arsenic were also recorded within the Birimian formation. About $83 \%$ or higher manganese concentrations were recorded within the Biri- mian formation. No occurrence of poor water quality was recorded within the Obosum Super group.

From the iron concentration map developed (Fig. 8), zones of concentrations greater than 1 $\mathrm{mg} / \mathrm{l}$ are observed within the Birimian, Granitoids and the Tarkwaian Group in urban to periurban communities (i.e. Obuasi, Offinso, Juansa, etc.). The validation results for the iron concentration map were very good with less than $1 \%$ prediction standardised errors (Table 3 ) within all the formations. About $78 \%$ of the test data were located within their expected zones.

Overall, about $12 \%$ of available water quality problems were due to high iron concentrations. Although concentrations of up to $3 \mathrm{mg} / \mathrm{l}$ can be consumed without any health problems, aesthetic problems particularly colouring of utensils, laundry and sanitary wares, taste, appearance and unpleasant odour often leads to the abandonment of such boreholes boreholes (WHO, 2003). The cause of the poor water quality is attributed to the easy dissolution of some elements into the water (Nyarko et al., 2014), which usually occurs during the rock weathering processes leading to exchange of chemicals between the soil and water (Hesterberg, 1998; Yidana et al., 2008).

Table 6: Groundwater quality evaluation within the various geological formations

\begin{tabular}{|c|c|c|c|c|c|c|}
\hline $\begin{array}{l}\text { Geological } \\
\text { formation }\end{array}$ & $\begin{array}{l}\text { No. of } \\
\text { holes }\end{array}$ & $\begin{array}{l}\text { Parameter } \\
\text { GWCL standard }\end{array}$ & $\begin{array}{l}\mathrm{pH} \\
6.5-8.5\end{array}$ & $\begin{array}{l}\mathrm{Fe}(\mathrm{mg} / \mathrm{l}) \\
\leq 0.3\end{array}$ & $\begin{array}{l}\operatorname{Mn}(\mathrm{mg} / \mathrm{l}) \\
\leq 0.10\end{array}$ & $\begin{array}{l}\mathrm{NO}_{3}(\mathrm{mg} / \mathrm{l}) \\
\leq 10\end{array}$ \\
\hline Birimian & 846 & $\begin{array}{l}\text { Range } \\
\% \text { PWQ }\end{array}$ & $\begin{array}{l}3.7-6.3 \\
6.6\end{array}$ & $\begin{array}{l}0.3-5.5 \\
10.9\end{array}$ & $\begin{array}{l}0.12-3.29 \\
0.95\end{array}$ & $\begin{array}{l}13.6-46.9 \\
0.7\end{array}$ \\
\hline Granitoids & 521 & $\begin{array}{l}\text { Range } \\
\% \text { PWQ }\end{array}$ & $\begin{array}{l}5.0-6.0 \\
12.3\end{array}$ & $\begin{array}{l}0.3-6.0 \\
17.1\end{array}$ & $\begin{array}{l}0.12-3.69 \\
0.19\end{array}$ & - \\
\hline Tarkwaian & 161 & Range & $4.7-6.0$ & $0.3-6.0$ & 1.5 & $16.3-29.6$ \\
\hline $\begin{array}{l}\text { Kwahu- } \\
\text { Morago }\end{array}$ & 61 & $\begin{array}{l}\% \text { PWQ } \\
\text { Range } \\
\% \text { PWQ }\end{array}$ & $\begin{array}{l}8.1 \\
4.5-5.5 \\
4.9\end{array}$ & $\begin{array}{l}5.00 \\
- \\
0\end{array}$ & $\begin{array}{l}0.62 \\
- \\
0\end{array}$ & $\begin{array}{l}1.2 \\
- \\
0\end{array}$ \\
\hline
\end{tabular}




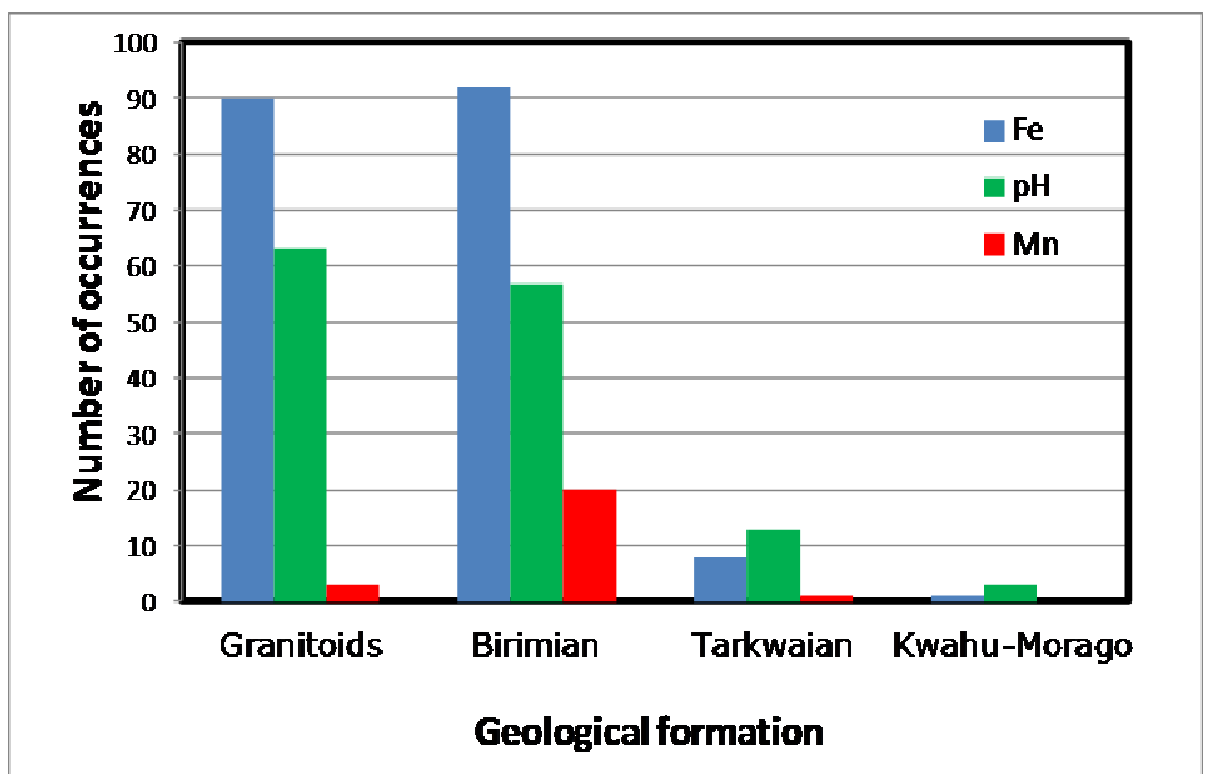

Fig. 7: Major poor water quality parameters in the geological formations

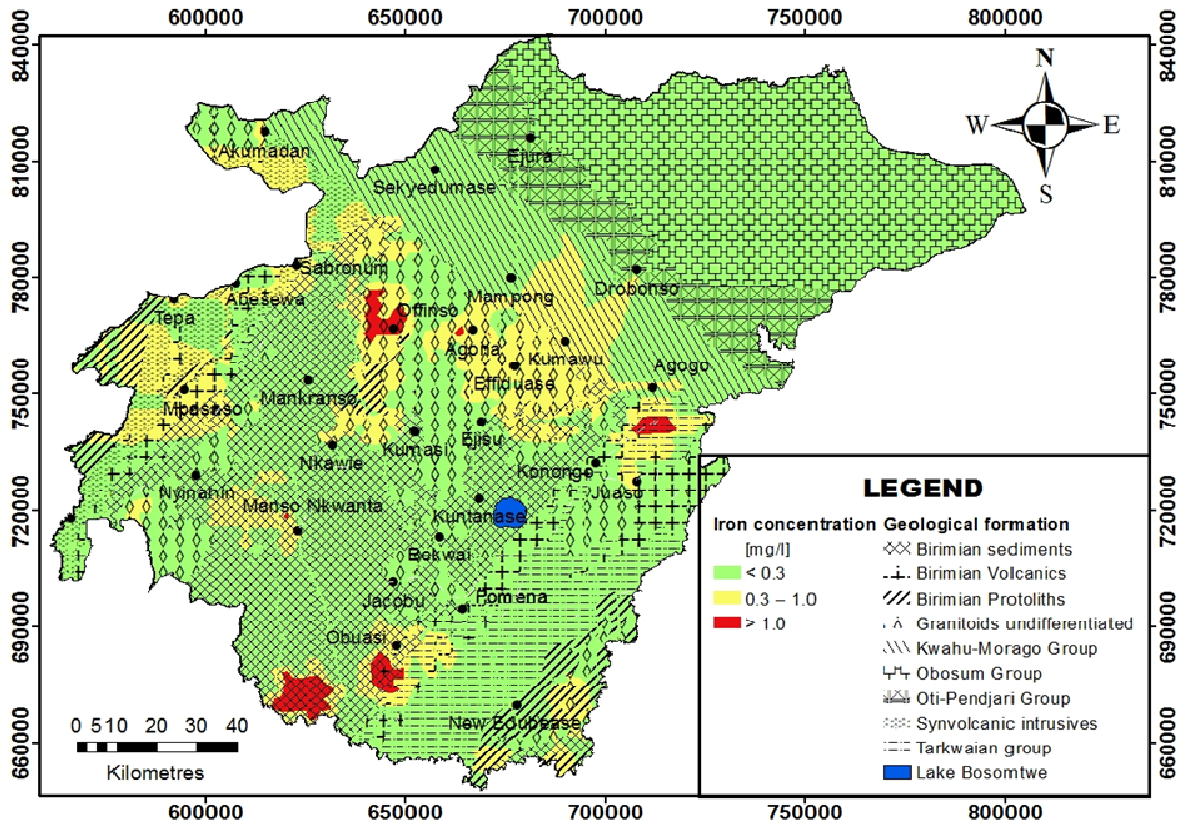

Fig. 8: Overlay of iron concentration on geological formation 
Evaluating the hydrogeology of Ashanti Region... 48

About 135of the boreholes had $\mathrm{pH}$ values below the Ghana Standard minimum value and one above the maximum value across all the geological formations except the Oti-Pendjari and Obosum Groups. According to Smedley et al. (1995), the problem of low acidity $(\mathrm{pH}<$ $6.5)$ in groundwater is often attributed to the deficiency of carbonate in the rocks. Furthermore, mining of gold and base metals can also lead to the oxidation of natural sulphides, thereby acidifying the groundwater and dissolving trace metals into it. Although its effect of mild sour taste has generally not been objected by consumers, water with low $\mathrm{pH}$ could leach metal ions from the aquifer (Oram, 2016). About $14 \%$ of the occurrences of $\mathrm{pH}$ outside the standard was with excess of other chemicals; $84 \%$ being iron.

About $31 \%$ of the PWQ boreholes had airlift yields within the CWSA criteria for Small Town Water Supply System. This is worrisome as high-yielding aquifers, which should be helping to solve water shortage problems are unwholesome for household and commercial usage. These are generally attributed to the geology, as evidenced by the location of the few cases of high concentration of arsenic within the Birimian sediments in the Obuasi Municipality, which are attributed to the presence of arsenopyrites in close association with sulphide mineralised veins.

\section{CONCLUSIONS}

The hydrogeological parameters of the geological formations (i.e. Birimian, the undifferentiated granitoids, Tarkwaian and Voltaian) in Ashanti Region were evaluated in this study with the production of maps for airlift yield, overburden thickness, depth of successful boreholes, static water level, specific capacity and iron concentrations with the aid of ArcGIS employing the ordinary kriging interpolation method. The study results indicate that the Birimian formation generally falls within the medium yield (30 - 60 1/min) and high yield (> $60 \mathrm{l} / \mathrm{min}$ ) zones, has specific capacity range of $0.21-99.65 \mathrm{~m}^{2} /$ day and a success rate of 90.6
$\%$ whilst the Granitoids have $72 \%$ drilling success rate and are generally low-yielding (less than $30 \mathrm{l} / \mathrm{min}$ ) with specific capacity values in the range of $0.3-88.5 \mathrm{~m}^{2} /$ day. The Tarkwaian Group had a drilling success rate of $79.5 \%$ and is generally within the low and medium yield zones with specific capacity ranging between 0.3 and $65.1 \mathrm{~m}^{2} /$ day. The Voltaian sub-groups that underlie the region registered the lowest yields except in the predominantly sandstones areas, which were high yielding. The success rate for the Kwahu-Morago, Oti-Pendjari and Obosum groups are respectively $53.5 \%, 60 \%$ and $66.7 \%$ while their respective specific capacities range from $0.2-72 \mathrm{~m}^{2} /$ day, $0.4-33$ $\mathrm{m}^{2} /$ day and $0.4-48 \mathrm{~m}^{2} /$ day.

The Voltaian formation had the lowest overburden depth in comparison with the other formations, which ranged between 20 and $30 \mathrm{~m}$. On the other hand, the static water elevation of the study area was observed to mimic the general topography. About $21 \%$ of the successful boreholes had high concentrations of iron and manganese, and low $\mathrm{pH}$. These were predominant within the Birimian, undifferentiated granitoids and the Tarkwaian formations.

The results from the study may serves as a useful practical information for groundwater development in the region. However, it may be improved by conducting further studies within the delineated zones to ascertain the continuity and hydraulic properties of the aquifers.

\section{ACKNOWLEDGEMENT}

The authors are grateful to the Ashanti Region branch of the CWSA, Directors of Geohydrotech Limited, Centre for Remote Sensing and Geographical Information Services and the GIS Laboratory of KNUST for providing the data for this study.

\section{REFERENCES}

Acheampong, S. Y. and Hess, J. W. (1998). "Hydrogeologic and hydrochemical framework of the shallow groundwater system in the Southern Voltaian Sedimentary Basin, 
Ghana”. Hydrogeology Journal, 6: 527 537.

Anornu, G. K., Kortatsi, B. K. and Saeed, Z. M. (2009). "Evaluation of groundwater resources potential in the Ejisu-Juaben District of Ghana". African Journal of Environmental Science and Technology, 3 (10): 332 - 340.

Asomaning, G. (1993). "Groundwater resources of the Birim basin in Ghana". Journal of African Earth Sciences (and the Middle East), 15 (3 - 4): 375 - 384.

Carrier, M. A., Lefebvre, R., Racicot, J. and Asare, E. B. (2008). "Groundwater recharge assessment in northern Ghana using soil moisture balance and chloride mass balance". GeoEdmonton, 8: 1437 - 1444.

Chenini, I., Mammou, A. B. and May, M. E. (2010). "Groundwater recharge zone mapping using GIS-based multi-criteria analysis: a case study in Central Tunisia (Maknassy Basin)". Water Resource Management, 24 (5): $921-939$.

Community Water and Sanitation Agency (CWSA)(2010). Sector guidelines: small communities design guideline. CWSA, Ghana.

Cook, G. P. (2003). A guide to regional groundwater flow in fractured rocks aquifers. CSIRO Land and Water, Australia.

Dapaah-Siakwan, S. and Gyau-Boakye, P. (2000). "Hydrogeologic framework and borehole yields in Ghana". Hydrogeology Journal, 8: 405 - 416.

Geological Survey Department (GSD) and Bundesantaltfür Geowissenschaften und Rohstoffe (BGR) (2009).Geological map of Ghana. Geological Survey Department, Accra.

Ghana Statistical Service (GSS) (2013).
"Analytical report of the 2010 population and housing census". Ghana Statistical Service, Accra.

Gill, H. E. (1969). A groundwater reconnaissance of the Republic of Ghana, with a description of geohydrologic provinces. Geological Survey Water Supply Paper 1757K.USGS, Washington.

Gyau-Boakye, P. and Dapaah-Siakwan, S. (2000)."Groundwater as source of rural water supply in Ghana”. Journal of Applied Science and Technology, 5 (1\& 2): 77 - 86.

Hesterberg, D. (1998). "Biogeochemical cycles and processes leading to changes in mobility of chemicals in soils". Agriculture, Ecosystem and Environment, 67: 121 - 133.

Kesse, G. O. (1985). The mineral and rock resources in Ghana. A. A. Balkema, Rotterdam.

Kresic, N. and Mikszewski, A. (2013). Hydrogeological conceptual site models; data analysis and visualisation, CRC Press, Boca Raton.

Machiwal, D., Jha, M. K. and Mal, B. C. (2011)."Assessment of groundwater potential in a semi-arid region of India using remote sensing, GIS and MCDM techniques". Water Resource Management, 25: 1359 - 1386.

Ministry of Local Government and Rural Development (MLGRD) (2016). Ashanti Region: location. Ministry of Local Government and Rural Development and Maks Publications \& Media Services. http:// www.ghanadistricts.com/regional.aspx? ashanti\&r=1 (accessed on July 12, 2016).

Nyarko, S. O., Tagbor, T. A. and Ofosu, B. (2014). "Assessment of chemical quality of groundwater over some rock types in Ashanti Region". American Journal of Scientific and Industrial Research, 5 (1): 1 - 6. 
Evaluating the hydrogeology of Ashanti Region... 50

Oram, B. (2016). The pH of Water. Water Research Watershed Centre, Pennsylvania. http://www.water-research.net/index.php/ph (accessed March 10, 2016).

Singhal, B. B. S. and Gupta, R. P. (1999). Applied hydrogeology of fractured rocks. Kluwer, Dordrecht.

Smedley, P. L., Edwards, W. M., West, J. M., Gardner, S. J. and Pelig-Ba, K. B. (1995). Health problems related to groundwater in the Obuasi and Bolgatanga areas, Ghana. British Geological Survey, Technical Report WC/95/43.British Geological Survey, Nottingham.

Talabi, A. O. and Tijani, M. N. (2011).
"Integrated remote sensing and GIS approach to groundwater potential assessment in the basement terrain of Ekiti area south-western Nigeria". RMZ - Materials and Geoenvironment, 58 (3): 303 - 328.

World Health Organisation (2003). Iron in groundwater: background document for development of WHO guidelines for drinkingwater quality. WHO, Geneva.

Yidana, S. M., Ophori, D. and BanoengYakubo, B. (2008). "Hydrogeological and hydrochemical characterisation of the Voltaian Basin: The Afram Plains area, Ghana". Environmental Geology, 53: 1213 - 1223. 